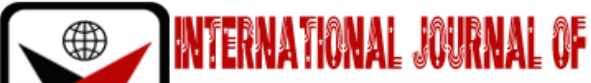 \\ בmas
}

ISSN 2278-0211 (Online)

\section{Uniqueness of Gothic Style in Cathedral Church of Chirst in No 29 Marina Road, Lagos Island, Lagos, Nigeria}

\begin{tabular}{|c|}
\hline Titilayo Anifowose \\
Lecturer, Department of Architecture, \\
Bells University of Technology Ota, Nigeria \\
Pristelia Olubunmi Akinde \\
Lecturer, Department of Architecture, \\
Bells University of Technology Ota, Nigeria
\end{tabular}

\begin{abstract}
:
Every church has its own character that is peculiar to it because churches are compilations of unique signs in form of ornaments. The functions that take place in them are reflected in architectural style adopted in the construction of the church. The significance of architectural features meaning must be planned while interpretation given to the building characters by the Church liturgy in history determined congregants 'mode of worship. The Church become where symbols of religious language are used to express its faith and dispose all congregants to receive its vision and belief. Symbols are pictorial representations of beliefs. Choice of church forms depends on the liturgical requirements and symbolical architectural characters. The uniqueness in cathedral structures is of the hierarchy of Earth and Heaven and often reveals its meaning through the internal decoration of the building with frescos or mosaics. The aim of this research is to describe the features that distinguished Cathedral Church of Christ in No29 Marina road, Lagos Island, Lagos from other Cathedral Churches in Nigeria. Qualitative research method was used for this study; in-depth interview was conducted through spontaneous questions from the provost of the church and personal observation was conducted in the Cathedral. Place theory and sustainable theory was used to analyzed and presented the data collected. The church features and architectural concept of the cathedral was descriptively obtained from the provost. This study revealed that the cathedral church of Christ in Marina symbolizes the progression of the Christian soul towards Salvation. The cathedral was centrally planned. This study shows how Cathedral Church of Christ speaks volume about the built environment of the existing urban fabric, past historic, spiritual activities and symbolic expression of the church to congregants. This study advocates preservation from the perspective of sustainable principles of historical and socio-cultural practices for better adaptation of resources and concludes by recommending remedies towards conservations of Cultural/National heritage.
\end{abstract}

Keywords: Cathedral, symbolic, liturgy, cruciform, gothic

\section{Introduction}

Cathedral Churches are often oriented east/west, so that the worshippers focus on the rising sun that symbolizing the risen Christ. The architectural form of the building most frequently has the ground plan of a cross. This form is both functional and symbolic, its representation denotes the cross on which Jesus was crucified. The form function liturgically as it allows the building to be divided into sections where different activities take place and are occupied by different people, such as the clergy, the choir and the laity. The focal point of the building, which is the longer arm of the cross, is called the nave where worshippers congregate. The term is from the Latin word for ship. The cathedral is figuratively a ship bearing the people of God through the storms of life (Auden, 2011). The nave is also used for major processions, which gather or enter at the furthest door (liturgically usually called the West Door). The aisles on each side of the nave facilitate the movement of people within the building, without disrupting worshippers in the central space. The arms of the cross are called the transepts and often contain a number of chapels. Furthest from the main entry is the sanctuary where the Blessed Sacrament is laid on the altar or communion table for the consecration. 'Sanctuary' means 'Holy Place'. The word has passed into modern English with an altered meaning because traditionally a criminal who could gain access to this area without capture was thereby given the sanctuary of the church. Shorter Oxford English Dictionary stated that cathedral is a Christian church that contains the seat of a bishop. It is a sacred structure for worship, precisely a denomination with an Episcopal hierarchy for instance Anglican, Orthodox and Methodist churches, which serves as a bishop's seat and hence as the central church of a diocese, conference, or episcopate (New Standard Encyclopaedia, 1992).USCCB, (2000)defined Church as living temple or the building that the Christian community gathers to fellowship, to pray together and celebrate the eucharist. For a building to be called achurch it must be a house of prayer thatexpresses 
the presence of God and that is suited for the celebration of the sacrifice of Christ, as well as reflection of the community that believe in them.

Hence, Churches must be places 'suitable for sacred and liturgical celebrations, 'distinguished,' and attractive (USCCB,2000). How suitable a Church is for worship is determined by the architectural design of space and the application of ornaments that is used to decorate the building to reflects God's initiative and the community's faithful response. Church buildings have religious ornaments that beautify, instigate and reflect the prayer of the community as well as the inner life of grace. Architecture and ornaments become the joint work of the Holy Spirit and the local community that is preparing human hearts to receive God's word and to enter more fully into realm of the spirit. The Church is the body of Christ and it provides for the intimate relationship between man and God (Geneva: World Council of Churches, 1982).Cathedral Church of Christ located at no 29 Marina Road, Lagos Island is a Gothic architecture with a unique feature that distinguished it from other Anglican Churches in Nigeria. The unique features are the pointed arches, the ribbed vaults, and the flying buttresses. The Gothic style used in the Cathedral Church of Christ Marin a stressed perpendicularity and luminosity of the cathedral significance. The gothic style of the Church was achieved through combination of certain architectural features that provided an engineering result. The structural members of the building are the gangatic columns, pointed ribbed vaults and flying buttresses. One of the defining characteristics of Gothic architecture is the pointed arch.

\section{Literature Review}

\subsection{The Structure Called Church}

At the beginning of fourth centuries most Christian communities worshipped in their individual homes in isolation. Few Roman churches, like the Basilica of San Clemente in Rome, were constructed on the buildings that early Christians revered God. Some early Roman churches were built on the sites of Christians torture or at the entrance to tombs where Christians were buried (Wikipedia Encyclopaedia, 2007). With the victory of the Roman emperor Constantine at the Battle of Milvian Bridge in 312 AD, Christianity became legitimate and then the honored religion of the Roman Empire. The faith that was spread around the Mediterranean then was reflected in religion buildings. Christian architecture was made to link to civic and imperial forms and so the Basilica, a large rectangular meeting hall became general in east and west, as the model for churches, with a nave and aisles and sometimes galleries and clerestories. While civic basilicas had apses at both sides, the Christian basilica usually had a single apse where the bishop and presbyters sat in a stand behind the altar. While pagan basilicas had their focus on a statue of the emperor; Christian basilicas focused on the Eucharist as the symbol of the eternal, loving and forgiving God (Ibid). The first largest Christian churches were built in Rome and have their origins in the early 4th century. Several notable Roman's churches like Santa Maria Maggiore, San Giovanni in Laterano, and Santa Costanza have their foundation in the 4th century (Grabar, 1967)

\subsection{Atrium}

At the inception of church buildings by early Christian Communities they drew on one particular feature of the houses that preceded them, the atrium, or courtyard with a colonnade surrounding it. A fine example remains at the Basilica of San Clemente in Rome and another was built in the Romanesque period at Sant'Ambrogio, Milan. The descendants of these atria may be seen in the large square cloisters that can be found beside many cathedrals, and in the huge colonnaded squares or piazze at the Basilicas of St Peter's in Rome and St Mark's in. Venice and the Camposanto (Holy Field) at the Cathedral of Pisa (Wikipedia Encyclopaedia, 2007).

\subsection{The Cruciform Plan}

Most cathedrals of great churches have a cruciform plan. For instance, churches of Western European tradition, the plan is longitudinal, in the form of the socalled Latin Cross with a long nave crossed by a transept. The transept may be as strongly projecting as at New York Minister or not project beyond the aisles as at Amiens Cathedral (Wikipedia Encyclopaedia, 2007). Manyearliest churches of Byzantium have a longitudinal plan. At Hagia Sophia, Istanbul, there is a central dome, frame on one axis by two high semi-domes and on the other by low rectangular transept arms, the overall plan is square. A square plan in which the nave, chancel and transept arms are of equal length forming a Greek cross, the crossing generally triumphed by a dome of common form in the Orthodox Church.Some churches in Eastern Europe and Russia are built in this way. Churches of the Greek Cross form always have narthex or vestibule which stretches across the front of the church. This type of plan later played a part in the development of church architecture in Western Europe, most notably in Bramante's plan for St. Peter's Basilica (Fletcher, 2001)

\subsection{Symbolic Expression in Church Architecture}

Symbols are descriptive pictures of beliefs. Through pictures, symbolism is the most powerful way to reflect complex ideas and concepts. Symbols also offer typical and instant way to identify the uniqueness of anything connected to a faith tradition and they have provided inspiration in art and architecture among others. Christianity is represented everywhere in the world by the symbol of the cross. Cross as a symbolic expression depicts the central belief of Christianity which is the sacrifice and death of Jesus Christ of Nazareth. While the symbolic meaning of Jesus Christ on the cross is called a crucifix. Architecture of churches and cathedrals took symbolic structure, such as the spire depicting a finger pointing heavenward, the footprint of the cathedral based on the cross; the altar a place of sacrifice as well as a table for eating the Lord'smeal. Symbolism spreads across all facets of religious life, from words phrases through to buildings(online, 2012). 
Society assumes that architecture should link both ambitions of its establishments and their real needs. Variances in appearance, in planning differentiate the forms of architectural types (the building from the church, among others), the kinds of use (the Catholic from the Protestant church), and the traditions and customs of users (the English from the Swiss Protestant church). When architectural arrangements become the vehicles of content-in plan, elevation, and decoration-they are symbolic. Their symbolism can be understood consciously or unconsciously, by association (e.g., spire $=$ church) to a building one has seen before and by the fact that it suggests certain universal experiences (Encyclopaedia Britannica, 2012). Symbolism in architecture is regarded as theoreticalcluethatmerge together several constituents of passions, sentiment, desires, faiths and recollections into a unified whole. Symbolic architecture refers to the conventional interpretation of the architecture of the mind. For example, the dove is a symbol of the Holy Spirit that apparently cannot be described in a visible form. The cross is a symbol of redemption and salvation of mankind, else would have been difficult to represent. The symbolic architecture is the manner in which memory stores are related and the set of rules applied to the system (J Andrews, 1995). Symbols have been used in various ways in church design to depict divine realities.

\section{Context of the Study}

The Cathedral Church of Christ is situated at a strategic point in 29 Marina road, Lagos Island, Lagos state. Marina road is the economic hub of Lagos State where headquarters of most banks in Lagos state are located for instance United Bank of Africa, Wema Bank among others. According to the Provost Very Revd. Adebola Ojofeitimi of the Cathedral Church of Christ Marina, who welcomed us to the Cathedral. He took us round the Church and educated us on the history of the Church. Provost the Very Revd. Adebola Ojofeitimi of the Cathedral Church of Christ narrated that the Cathedral was the first Anglican Cathedral in Nigeria which is over 150years old. The church started in 1853 by Reverend Samuel AjayiCrowther, a Yoruba man from Abeokuta who was the first African bishop of Anglican Church. Who translated English bible to Yoruba language. In 1867 there was an increased in congregants that led to demand of a piece of land from Lagos state government for expansion. The land was given to the Church at the center of commerce which is Marina at the present location. The current Cathedral Church building was designed by a Lagos architect, Arc. Began Benjamin on $1^{\text {st }}$ of November, 1924 while construction of the Cathedral started in 1929 but the first foundation was laid on April $15^{\text {th }} 1925$ by his Royal Highest Edward Prince of Wales K.G.(who later became King Edward viii) and was completed in 1946. There is a place called Lady Chapel where communion takes place in the cathedral.

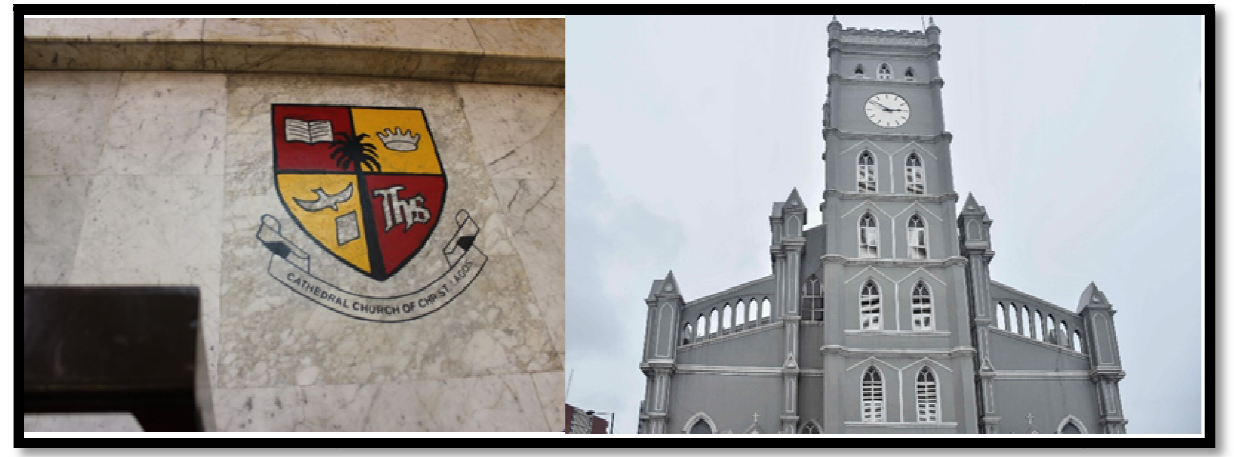

Figure 1: Showing Approach View of Cathedral Church of Christ in Marina Lagos Island and the Logo

\section{Methodology}

Qualitative research method was used for this study; in-depth interview was conducted through spontaneous questions from the provost of the churchandpersonal observation was conducted in the Cathedral. Place theory and sustainable theory was used to analyzed and presented the data collected.

\section{Results and Discussion}

\subsection{Concept of Design Plan}

The style of architecture used for the Cathedral is Gothic Style. It is in form of a cruciform(a cross)with a lengthy nave making the body of the church, a crosswise arm called the transept and an extension that may be called the choir and presbytery. The use of cardinal points was considered by having the main entrance at the west, two minor entrances by the north and south and the alter by east. The nave is fringed on either side by aisles. The nave is taller than the aisles, having clerestory windows which light the central space. We were told by the provost that women do not go close to the alter and are not members of the ushers and choir. On the right side of the alter is a pipe organ that was built by Oberlinger Orgelbau in Germany. It has two sides- one facing the alter and the other facing the right nave. The Church is decorated with different types of chandelier lights for illumination. In 1956, the Queen of England, Queen Elizabeth II visited the cathedral. The then provost was the late revered A.W. Howells. She brought a chair as a gift and that chair is still in the Church. 


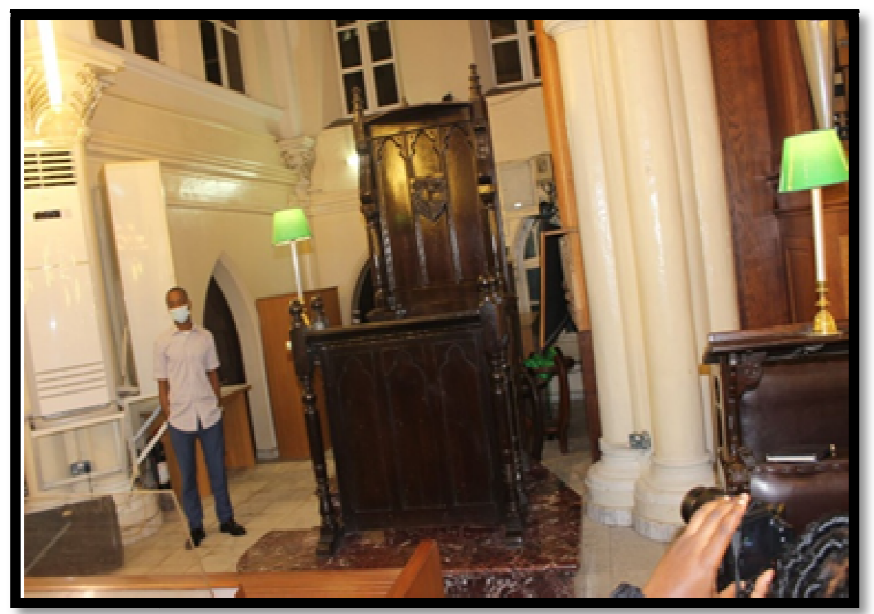

Figure 2: Showing the Seat That Made the Church Cathedral

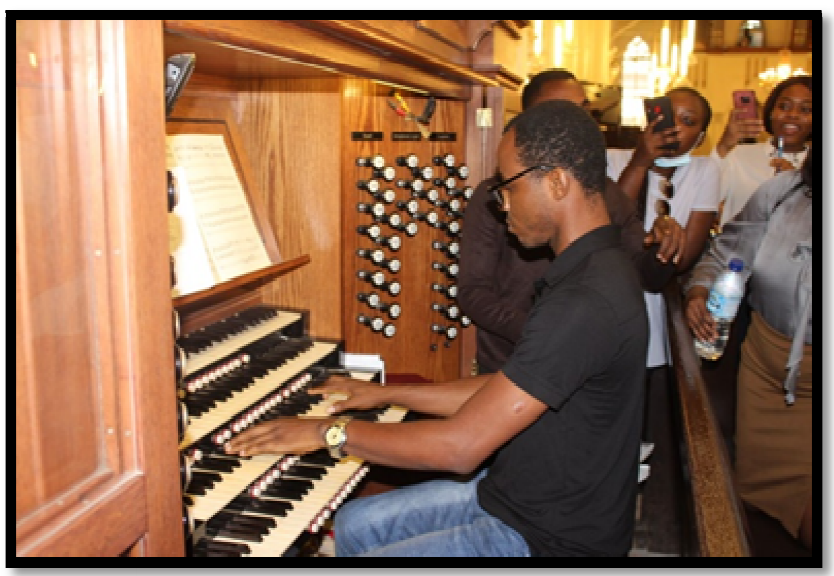

Figure 3: Showing the Pipe Organ Builtby Oberlinger Orgelbauin Germany

The Church is decorated with stained glass that have significant meaning to the Cathedral. They stained glass are washed and polished in United Kingdom. The last time it was taken to Uk for polishing was in 2016.The stained-glass window, erected in memory of Revered Samuel AjayiCrowther. There is a smaller section of the Church at the left side of the alter called the' Lady Church', where weekly services are held.

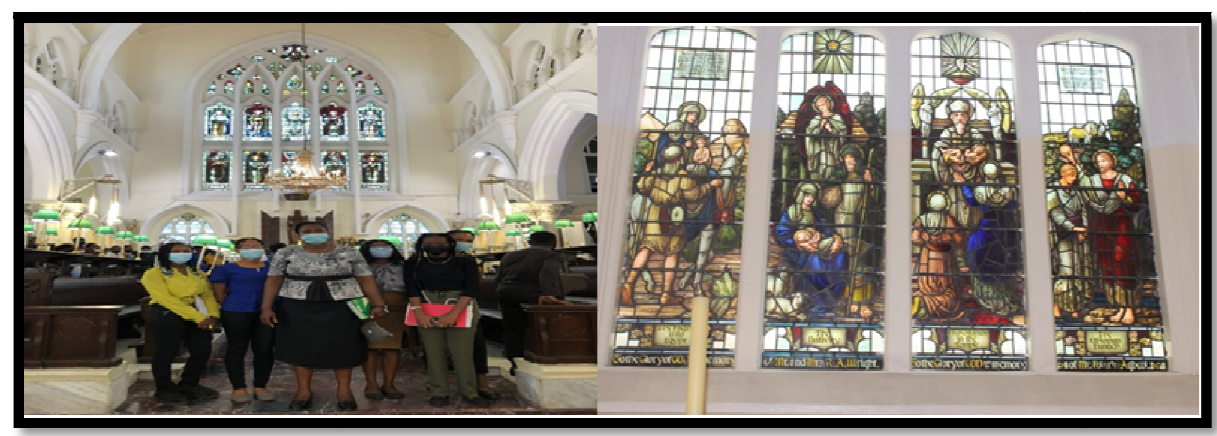

Figure 4: Showing the Interior Views of Cathedral Church Decorated with Stained Glasses

\subsection{Functions of the Features in the Cathedral}

The Gothic vault was used to roof the rectangular and irregularly shaped plans of the cathedral. The other structural advantage is that the pointed arch transfers the weight on the bearing piers or columns at a steep angle. This enabled the designer to raise vaults much higher than was possible in gothic architecture. While, structurally, use of the pointed arch gave a greater flexibility to architectural form, it also gave Gothic architecture a very different visual character. The verticality suggesting an aspiration to Heaven. In Gothic Architecture the pointed arch is used in every location where a vaulted shape is called for, both structural and decorative. Gothic openings such as doorways, windows, arcades and galleries have pointed arches. Gothic vaulting above spaces both large and small is usually supported by richly moulded ribs. Rows of pointed arches upon delicate shafts form a typical wall decoration known as blind arcading. Niches with pointed arches and containing statuary are a major external feature. The pointed arch lent itself to elaborate intersecting shapes which developed within window spaces into complex Gothic tracery forming the structural support of the large windows that are characteristic of the style. 


\subsection{Majestic Features of the Church}

The façade of a large church or cathedral, often referred to as the West Front, is generally designed to create a powerful impression on the approaching worshipper, demonstrating both the might of God, and the might of the institution that it represents. One of the best known and most typical of such façades is that of Notre Dame de Paris. Central to the façade is the main portal, often flanked by additional doors. In the arch of the door, the tympanum, is often a significant piece of sculpture, most frequently Christ in Majesty and Judgment Day. If there is a central door jamb or a tremeu, then it frequently bears a statue of the Madonna and Child. There may be much other carving, often of figures in niches set into the mouldings around the portals, or in sculptural screens extending across the façade. In the centre of the middle level of the façade, there is a large window, which in countries other than England and Belgium, is generally a rose window like that at Reims Cathedral. The gable above this is usually richly decorated with arcading or sculpture, or in the case of Italy, may be decorated, with the rest of the façade, with polychrome marble and mosaic, as at Orvieto Cathedral The West Front of a French cathedral and many English, Spanish and German cathedrals generally have two towers, which, particularly in France, express an enormous diversity of form and decoration. However, some German cathedrals have only one tower located in the middle of the façade (such as Freiburg Münster). Basic shapes of Gothic arches and stylistic character the way in which the pointed arch was drafted and utilized developed throughout the Gothic period. There were fairly clear stages of development, which did not, however, progress at the same rate, or in the same way in every country. Moreover, the names used to define various periods or styles within the Gothic differ from country to country.

\subsection{Description of some Unique Characters in the Church}

The exterior of the cathedral is painted in grey colour while the interior was painted in cream color. Cenotaph erected in memory of Reverend Samuel Ajayi Crowther at the right side of the church where Bishop Ajayi Crowther was buried. The floor of the cathedral was finished with marble tiles while a particular space was inscribed with cathedral logo on the floor of the Church. The is a Seat that belongs to the archbishop the Primate of all Nigeria of the Anglican Church and it is only archbishop of the Ecclesiastical province of Lagos alone that is allow to sit on this seat.Presently it is the seat of the bishop of Lagos. The seat was given to the Church by Queen Elizabeth II(The Queen of England) when she visited Nigeria in 1956. According to the Provost it is this seat that qualified the Church to be called Cathedral. There is an Organ piano built by Oberlinger Orgelbau from Germany at the right side of the altar with two facades- one facing the altar and the second one facing the right nave. The organ is one of its kind in Nigeria that was purchased for about 160million naira in 2005. At the beginning of $21^{\text {st }}$ century the organ was renewed by an English company Harrisson \& Harrisson; the organ consists of 64 stops on 4 manuals and a pedalboard. It is only male choir that participate in choir activities in this Church. There are some stained Glasses that tell stories of the birth and death of our lord Jesus Christ from when the angel appeared to Mary the mother of Jesus. The grave of Bishop Samuel Ajayi Crowtherthe first African bishop of West Africa is within the Cathedral. They are four bells located on top of Cathedral that rings by $1 \mathrm{p} . \mathrm{m}$ every day.

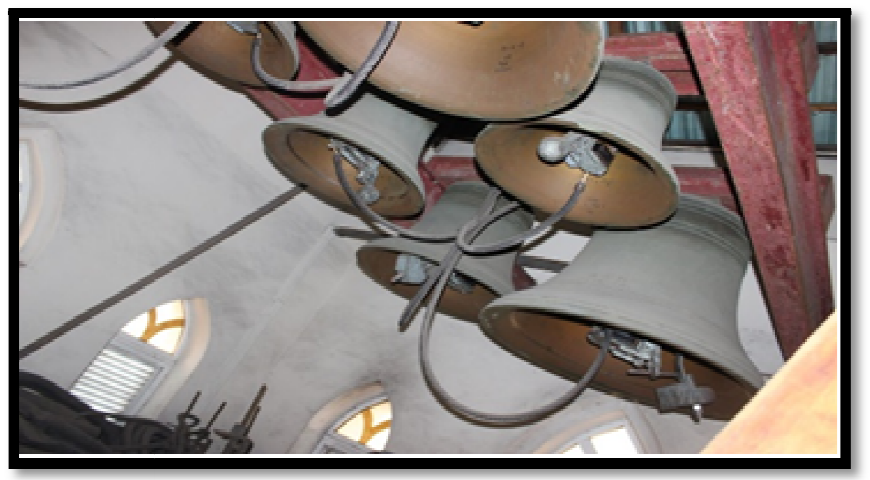

Figure 5: Showing the Bells That Rings by 1.P.M

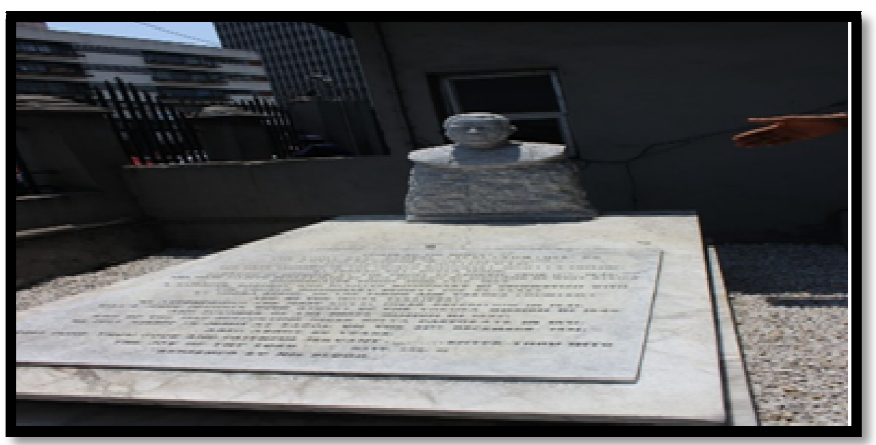

Figure 6: Showing Cenotaph of Bishop Ajayi Crowthe 


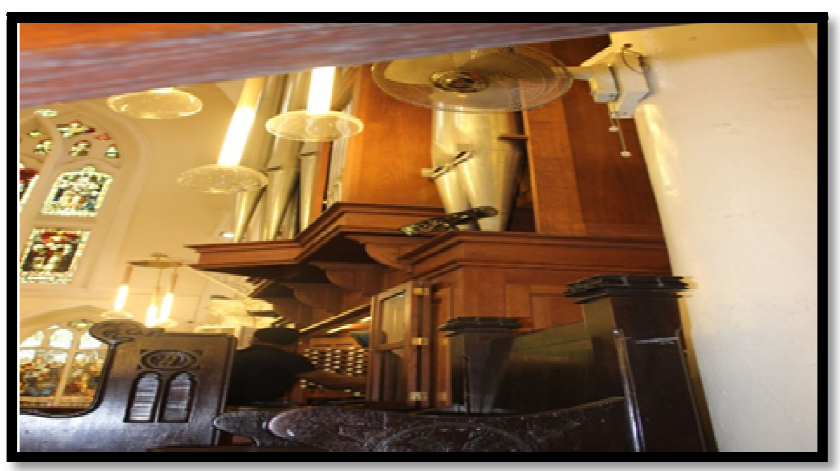

Figure 7: Showing the Unique and Expensive Pipe Organ in Cathedral Church of Christ Marina

\section{Conclusion and Recommendation}

This study revealed unique characters in the design concepts of Cathedral Church of Christ Marina as a cathedral of its kind in Nigeria. Considering the magnificent features of gothic style put in place to display the supremacy of God in place of worship with the view of creating striking and artistically appealing architectural and symbolic piece(s) in place of worship. This study showed how the unique characters of the Cathedral were put in place and when they were incorporated into the Cathedral. Finally, this study revealed what distinguished the Cathedral Church of Christ Marina from every other Anglican Cathedrals in Nigeria. This study advocates preservation from the perspective of sustainable principles of historical and socio-cultural practices for better adaptation of resources and concludes by recommending remedies towards conservations of Cultural/National heritage.

\section{References}

i. Andjelich, L (1993). An Orthodox Celebration Space: Reinterpreting Tradition (pp. 41- 48).

ii. Andrews J. (1995), Symbolic Architecture. New York: Lumen Books

iii. Auden, W. H. (2011): 'Cathedrals, Luxury liners laden with souls, Holding to the East their hulls of stone'Baptism, Eucharist, and Ministry, WCC Faith and Order Paper No. 111 (Geneva: World Council of Churches, 1982).

iv. Bartlett, W. H., The Scenery and Antiquities of Ireland. Circa 1841, Vol. 1

v. Church Architecture. 2007. Wikipedia freeEncyclopaedia 2007. Retrieved November 11, 2011, from http://en.wikipedia.org/wiki/Church_architectureu/

vi. Encyclopædia Britannica Inc., 2012. Web. 11 May. 2012

vii. Fletcher, B. (2001). A History of Architecture on the Comparative method, 2001, Elsevier Science \& Technology, ISBN 0-7506-2267-9.

viii. Grabar, A.(1967): The Beginnings of Christian Art. Thames and Hudson, ISBN Hammond, P. (1961): Liturgy and Architecture, Columbia University Press, New York.

ix. Inc (USCCB), Built of Living Stones: Art, Architecture, and Worship. November 16, 2000. Ward-Perkins, J. B. (1994).

x. New Standard Encyclopaedia, 1992.

xi. United States Conference of Catholic Bishops, Inc (USCCB), Built of Living Stones: Art, Architecture, and Worship. November 16, 2000. 